\title{
橋によるレーダー偽像の理論的考察
}

$\begin{array}{ccc}\text { 鈴木 } & \text { 務* }, \text { 荒井 郁男*，木村 小一** } \\ \text { 庄司 和民***, 飯島 幸人***, 杉崎 昭生*** } \\ \text { 今津 隼馬***, 林 尚吾*** }\end{array}$

\section{Theoretical Considerations in the Radar False Echoes Produced by a Bridge}

\author{
Tsutomu SUZUKI, Ikuo ARAI, Koichi KIMURA, \\ Kazutami SHOJI, Yukito IIJIMA, Akio M. SUGISAKI, \\ Hayama IMAZU and Shogo HAYASHI
}

\begin{abstract}
In a recent year, it has been pointed out that the steel bridges crossing over the waterways sometimes produce the false echoes. To determine whether such echoes cause navigational hazards or not, we must know the false-echo levels.

In this paper, we first get the radar equations for the false echoes, and point out the necessity of the radar cross section of a bridge to calculate the echo levels. Second, we consider theoretically how to calculate the radar cross section of the complex reflectors such as a bridge.

The calculated results of the radar cross section of a bridge agree approximately with the measured values obtained from Oshima-Ohashi Bridge.
\end{abstract}

1. はじめに

レーダーで橋を観测すると橋の形状が広がって見えたり，ひずんで見えたりする現象が見られる。このような 場合も橋の形状の判別を誤ったり，橋のすぐをばにある他船が橋のエコーで隠されるなどの問題を生じるが，航 海者によって最も危険なのは偽像が航路上付近に生じ，他船のエコーを隠したり，他船と鿁って判定しやすい場 合である。乙のようなレーダ一偽像に対し適切に対処するには橋による偽像レベルを定量的に把握することが必 要となるが，この試みは過去に例がない。そとで，本文は橋によるレーダ一偽像の受信電力レベルを理論的に求 める方法を考察する。

\section{2. 偽像発生のメカニズム}

図 1 のごとく船 $S$ がレーダーアンテナを回転しながら橋に接近する場合を考える。アンテナの回転によって レーダービームが照射する橋の部分が順次左から右へと移動する。図 1 にはレーダービームが $B$ 点を照射して いるときを示す。 $B$ 点に当てられた電波は橋から反射される。橋の構成材料は複雑な形状，配置をして颃り，単 なる平面とは限らないので複雑な反射指向特性をすって電波が散乱する。いま橋への入射角 $\theta_{i}$ 亿対して，反射 争 $\theta_{r}$ 方向に建物や山などの物標 $T$ があると，その物標に反射電波が当たり，物標で反射され，再び橋で反射

* 正会員 電気通信大学 (調布市調布ヶ丘 1-5-1)

** 正会員 運輸省電子航法研究所 (三鷹市新川 6-38-1)

*** 正会員 東京商船大学 (江東区越中島 2-1-6) 


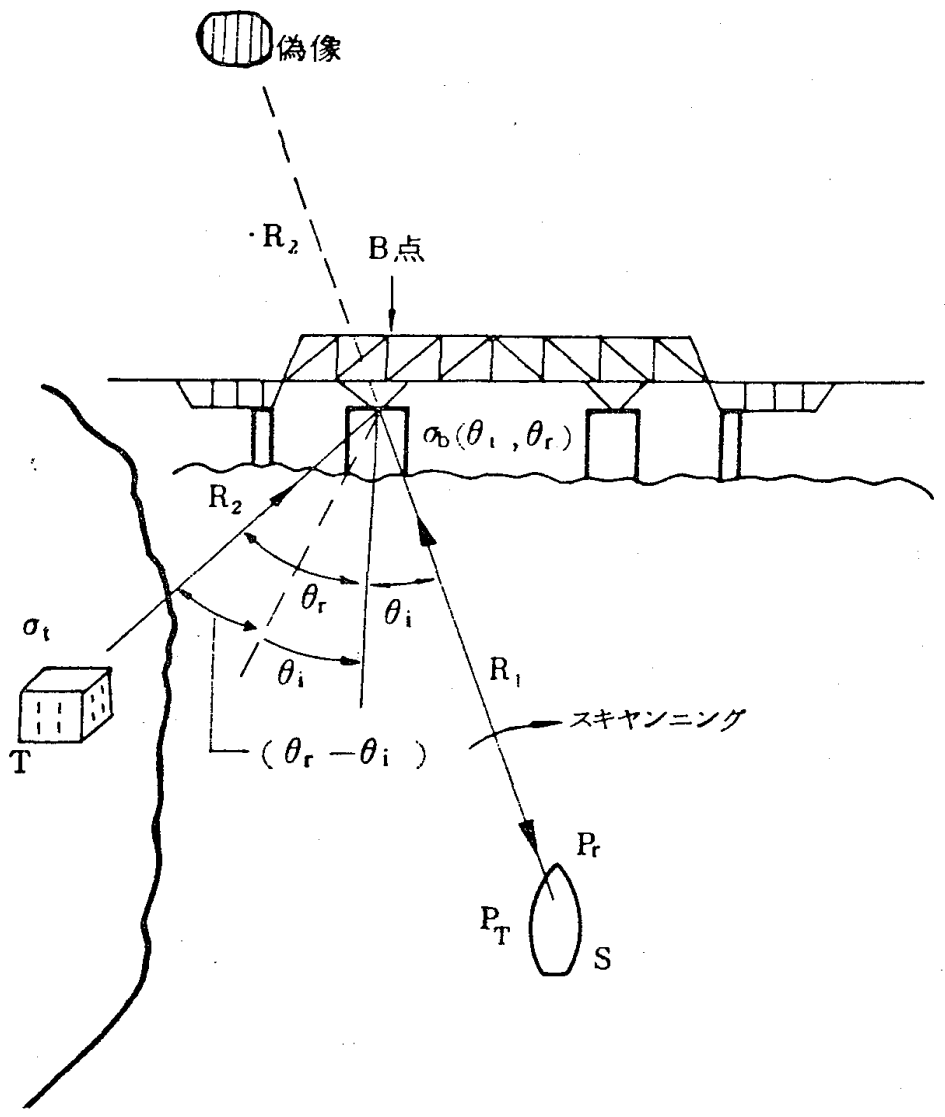

図 1 偽像発生とその強さの説明図

$G_{T}$ ：送信アンテナ利得

$A_{R}:$ 受信アンテナ実効開口面積

$R_{1}$ ：船亡橋の照射点との距離

$R_{2}$ ：照射点と近傍物標との距離

$\sigma_{t}:$ 物標のレーダー反射断面積

$\sigma_{b}\left(\theta_{i}, \theta_{r}\right)$ : 入射角 $\theta_{i}$, 反射角 $\theta_{r}$ に括ける橋のレーダー反射断面積

$\sigma_{b}\left(\theta_{r}, \theta_{i}\right)$ : 入射角 $\theta_{r}$, 反射角 $\theta_{i}$ に拉ける橋のレーダー反射断面積 である。

実際には, $\theta_{b}\left(\theta_{i}, \theta_{r}\right) \fallingdotseq \theta_{b}\left(\theta_{r}, \theta_{i}\right)$

$$
\text { , } A_{R}=\frac{\lambda_{0}^{2} G_{R}}{4 \pi}
$$

$\lambda_{0}$ は使用電波の波長， $G_{R}$ は受信アンテナの利得である。

図 2 に示すごとく現実には距 離 $R$ に比較してアンテナ高 $h_{1}$ や橋の高さ $h_{2}$ が小さいので, 海面で電波が反射して，照射点 $B$ では直接波と反射波との合成 した電波が当たると考えられ る。また，逆経路で橋から反射 した電波が船に戻る場合あ同様 に直接波と反射波”の合成とな る。橋と陸上さの間でも，この
されてから船上のレーダ一受信機で受信され る。との場合にアンテナは橋の $B$ 点に河っ ているので，偽像は船と $B$ 点との延長上に 生じ， $B$ 点と物標 $T$ 亡の間の距離 $R_{2}$ 亡等 しい距離だけ $B$ 点から離れた地点に偽像を生 じる。すなわち，レーダー指示器上には $B$ 点 の方向に船加ら（船と $B$ 点との距離 $R_{1}$ ) + ( $B$ 点亡物標との距離 $R_{2}$ ) の位置に偽像が現 われる。アンテナの回転に従って照射点が $B$ から橋上を次々と移動する。

航路に近い力向にある橋の部分を照射したと きに生ずる偽像は最も注意を要するエコーと 考えられる。

\section{3. 偽像のレーダー方程式}

四 1 亿示す位置関係に执いて船上 $S$ におい て受信される偽像の受信電力は直接波のみに ついて考えると

$$
\begin{aligned}
P_{r} & =\frac{P_{T} \cdot G_{T} \cdot A_{R}}{(4 \pi)^{4} \cdot R_{1}{ }^{4} \cdot{R_{2}}^{4}} \sigma_{t} \cdot \sigma_{b}\left(\theta_{i}, \theta_{r}\right) \\
& \times \sigma_{b}\left(\theta_{r}, \theta_{i}\right) \quad(\mathrm{w}) \quad(1)
\end{aligned}
$$

で表わされる。

$P_{T}:$ レーダー送信電力 
ような反射波干渉を考慮すると偽像電力のレーダー方程式は

$$
\begin{aligned}
P_{r}^{\prime} & =\frac{P_{T} \cdot G_{T} \cdot A_{R}}{(4 \pi)^{4} \cdot R_{1}{ }^{4} \cdot R_{2}{ }^{4}} \cdot \sigma_{t} \cdot \sigma_{b}{ }^{2}\left(\theta_{i}, \theta_{r}\right) \cdot 4^{4} \\
& \times \sin ^{4}\left(\frac{2 \pi h_{1} h_{2}}{\lambda_{0} R_{1}}\right) \cdot \sin ^{4}\left(\frac{2 \pi h_{2} h_{3}}{\lambda_{0} R_{2}}\right) \quad(\mathrm{w})
\end{aligned}
$$

となる。乙こで $h_{1}$ は船のレーダーアンテナの高さ， $h_{2}$ は橋の照射点の高さ， $h_{3}$ は近傍物標の高さである。

（2）式で示した偽像レベルは最大值に扔いて直接波のみによる偽像レベル $P_{r}\left((1)\right.$ 式）より $4^{4}$ 倍すなわち $24 \mathrm{~dB}$ あ多く受信されたととになる。すしす橋と物標との間の地上の反射点が陸上にあると，海面反射のように 反射波が強くならないので直接波のみについて考えればよく，船之橋との間の海面反射のみ干渉があるとすると 偽像電力 $P_{r}^{\prime \prime}$ は

$$
\begin{aligned}
P_{r}^{\prime \prime} & =\frac{P_{T} \cdot G_{T} \cdot A_{R}}{(4 \pi)^{4} \cdot R_{1}^{4} \cdot R_{2}{ }^{4}} \cdot \sigma_{t} \cdot \sigma_{b}{ }^{2}\left(\theta_{i}, \theta_{r}\right) \cdot 4^{2} \\
& \times \sin ^{4}\left(\frac{2 \pi h_{1} h_{2}}{\lambda_{0} R_{1}}\right) \quad(\mathrm{w})
\end{aligned}
$$

となり， $P_{r}{ }^{\prime \prime}$ の最大值は直接波のみの $4^{2}$ 倍，すなわち $12 \mathrm{~dB}$ 高いレベルで受信される。

大島大橋 (大皇瀬戸) 付近の観測に䄧いて，偽像が出現したレベルと使用したレーダーの諸元から計算した偽 像レベルを比較すると，船と橋との間の海面反射のみを考慮すればよいととが，判明したのでレーダー偽像レべ ルの計算には（3）式を用いることにした。すなわち直接波レベルに $12 \mathrm{~dB}$ 加えた值を偽像レベルに採用する。 そこで，最大值としては（3）式ょり

$$
P_{r}^{\prime \prime \prime}=\frac{P_{T} \cdot G_{T} \cdot A_{R}}{(4 \pi)^{4} \cdot R_{1}^{4} \cdot R_{2}{ }^{4}} \cdot \sigma_{t} \cdot \sigma_{b}{ }^{2}\left(\theta_{i}, \theta_{r}\right) \cdot 4^{2} \quad(\mathrm{w})
$$

を偘像レベルの計算に使用するととにした。

\section{4. 橋のレーダー反射断面積}

（4）式を用いて偽像レベルを計算する場合に， $\sigma_{t}$ 之 $\sigma_{b}$ 以外はレーダーの仕様と距離測定から求められる。物 標の反射断面積 $\sigma_{t}$ は個々の物標毎に入射角の関数之なる。

そこで，橋の照射点近くにレーダーを設置して，物標每に反射断面皘を観測で求めた。地図上に近傍物標のレ 一ダー反射断面積の強度分布を示したすのをエコーレベルマップとよぶ。四 3 はエコーレベルマップをとるとき の配置図を示す。橋の照射点付近に船を停船させ, 船上レーダーで物標からの反射電力を観測する。例えば, 物 標 $a$ からの反射電力を $P_{a}$ とすると

$$
P_{a}=\frac{P_{r} \cdot G_{T} \cdot A_{R}}{(4 \pi)^{2} \cdot R_{a}{ }^{4}} \cdot \sigma_{a}
$$

となる。（5）式は $\sigma_{a}$ の評価を厳しくするため，直 接波のみの式を用いた*。

（5）式上り物標 $a$ のレーダー反射断面積 $\sigma_{a}$ は

$$
\sigma_{a}=\frac{P_{a} \cdot(4 \pi)^{2} \cdot R_{a}{ }^{4}}{P_{T} \cdot G_{T} \cdot A_{R}}\left(\mathrm{~m}^{2}\right)
$$

となる。受信電力 $P_{a}$ 之距離 $R_{a}$ を観測すれば，そ の物標のレーダー反射断面皘 $\sigma_{a}$ が（6）式から求め られる。

橋のレーダー反射断面積 $\sigma_{b}\left(\theta_{i}, \theta_{r}\right)$ は, 物標への 入射角 $\theta_{i}$ 之反射角 $\theta_{r}$ が異なる場合に， その物標 のレーダー反射断面積を bistatic radar cross section



図 3 各物標からの反射エコーマップの作成の説明図

* 海面反射を考えると（6）式は $\sigma_{a}=\frac{P_{a} \cdot(4 \pi)^{2} \cdot R_{a}^{4}}{P_{T} \cdot G_{T} \cdot A_{R}} \frac{1}{4^{2}}$ と，小さく評価される。 
とよぶ。 bistatic radar cross section は入射角 $\theta_{i}$ と反射角 $\theta_{r}$ 関数となる。実際の橋のような複雑な構造体から のレーダー反射断面積を計算で厳密に求めることは困難である。単純な形状については計算例があるので，橋の 実際のレーダ一反射断面積を観測して，その值から等価的な単純形状の集合として橋のレ一ダ一反射盺面積の理 論式を導く方法をとることにする。

入射と反射が同じ場合に物標が示す反射断面積を monostatic radar cross section がとよぶ。

図 4 に示すごとく矩形板， $a \times b$ ， に斜めに電波を照射したときの monostatic 断面積 $\sigma_{b}(\theta, \phi)$ は，矩形板を 完全平面とし， $a \gg \lambda_{0}, b \gg \lambda_{0}$ とすると,

$$
\begin{aligned}
\sigma_{b}(\theta, \phi) & =\frac{4 \pi}{\lambda_{0}{ }^{2}} A^{2} \cdot \cos ^{2} \theta \cdot \cos ^{2} \phi \cdot\left[\frac{\sin \left(K_{0} a \sin \theta \cdot \cos \phi\right)}{K_{0} a \sin \theta \cdot \cos \phi}\right]^{2} \\
& \times\left[\frac{\sin \left(K_{0} b \sin \theta \cdot \sin \phi\right)}{K_{0} b \sin \theta \cdot \sin \phi}\right]^{2} \cdot\left[\frac{\sin \left(K_{0} b \sin \phi \cdot \cos \theta\right)}{K_{0} b \sin \phi \cdot \cos \theta}\right]^{2} \\
& \times\left[\frac{\sin \left(K_{0} a \sin \phi \cdot \sin \theta\right)}{K_{0} a \sin \phi \cdot \sin \theta}\right]^{2}
\end{aligned}
$$

ただし， $A=a \times b, K_{0}=2 \pi / \lambda_{0}, \lambda_{0}=$ 波長である。ととで，

垂直入射，垂直反射

$$
\sigma_{b}(0,0)=\frac{4 \pi}{\lambda_{0}^{2}} A^{2}=\frac{4 \pi}{\lambda_{0}^{2}}(a \times b)^{2}
$$

水平面入，反射

$$
\sigma_{b}(\theta, 0)=\frac{4 \pi}{\lambda_{0}{ }^{2}} A^{2} \cos ^{2} \theta \cdot\left[\frac{\sin \left(K_{0} a \sin \theta\right)}{K_{0} a \sin \theta}\right]^{2}
$$

垂直面入，反射

$$
\sigma_{b}(0, \phi)=\frac{4 \pi}{\lambda_{0}^{2}} A^{2} \cos ^{2} \phi \cdot\left[\frac{\sin \left(K_{0} b \sin \phi\right)}{K_{0} b \sin \phi}\right]^{2}
$$

となる。

図 5 に示すごとき斜材の反射断面積は $(x, y)$ 座標を $(\theta, \phi)$ 座標に変換することから求められる。指向特性 を气る関数 $D(\theta, \phi)$ は，

$$
D(\theta, \phi)=\left[\frac{\sin \left(K_{0} a x\right)}{K_{0} a x}\right] \cdot\left[\frac{\sin \left(K_{0} b y\right)}{K_{0} b y}\right]
$$

となる。ここで

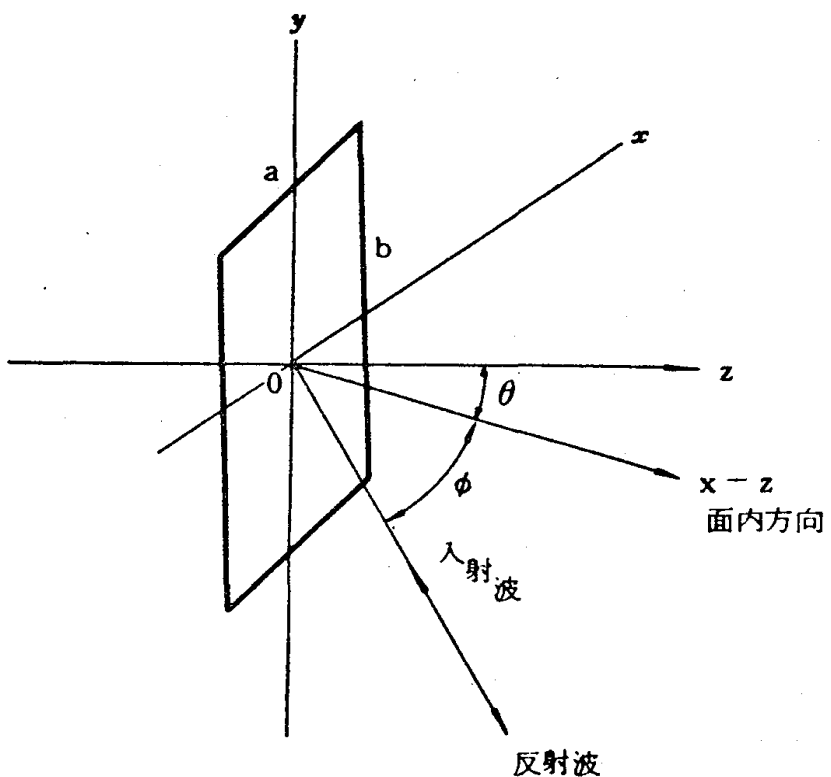

図 4 monostatic radar cross $\mathrm{S}$

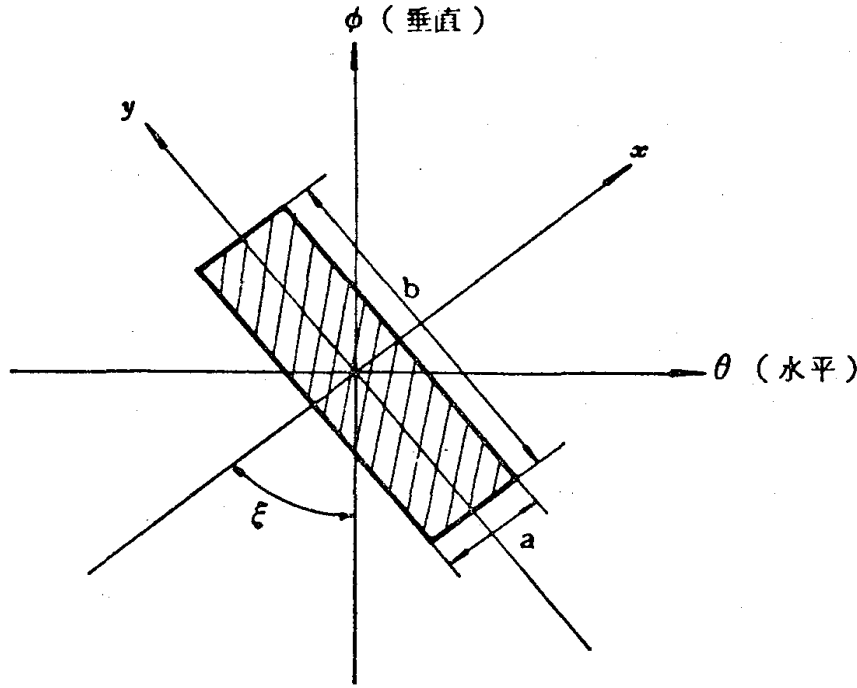

図 5 斜め部材のレーダー反射断面積 


$$
\left\{\begin{array}{l}
x=\theta \cdot \sin \xi+\phi \cdot \cos \xi \\
y=\theta \cdot \cos \xi-\phi \cdot \sin \xi
\end{array}\right.
$$

である。従って, monostatic 反射断面積 $\sigma_{b}(\theta, \phi)=\sigma_{b}(x, y)$ は，

$$
\begin{aligned}
& \sigma_{b}(x, y)=\frac{4 \pi}{\lambda_{0}^{2}}(a \times b)^{2} \cdot D^{2}(\theta, \phi) \\
& \therefore \quad \sigma_{b}(x, y)=\frac{4 \pi}{\lambda_{0}{ }^{2}}(a \times b)^{2} \cdot\left[\frac{\sin \left(K_{0} a x\right)}{K_{0} a x}\right]^{2} \cdot\left[\frac{\sin \left(K_{0} b y\right)}{K_{0} b y}\right]^{2}
\end{aligned}
$$

で求めるととができる。

bistatic cross section と monostatic cross section の換算方法を図 6 に示す。波長に比へて反射体の寸法が大 きい之き，入射角 $\theta_{i}$ ，反射角 $\theta_{r}$ の bistatic な反射断面積は，単位入射べクトル $\dot{A}_{i}$ 亡単位反射ベクトル $\dot{A}_{r} の$ ベクトルの和 $\dot{V}=\dot{A}_{i}+\dot{A}_{r}$ の方向の等洒 monostatic 反射と等しい*。

図6 から等価ベクトル $\dot{V}$ の方向 $\delta$ は,

$$
\delta=\frac{\theta_{r} \pm \theta_{i}}{2}
$$

となる。ととで複号は，入，反射方向が同一象限のとき+をとる。

図6の例では， $\delta=\left(\theta_{r}-\theta_{i}\right) / 2$ の方向の monostatic 反射断面積と等しくなる。そこでbistatic な反射を monostatic な反射として計算できる。

$$
\sigma_{b}(\theta)=\sigma_{b}(0) \cdot \cos ^{2} \delta\left[\frac{\sin \left(K_{0} a \delta\right)}{K_{0} a \delta}\right]^{2}
$$

となる。鏡面反射 $\theta_{i}=\theta_{r}$ では， $\delta=0$ となる。

$$
\therefore \sigma_{b}(\theta)=\sigma_{b}(0)
$$

となり，垂直入，反射と等しい。

入射波亡反射波が同一の象限にある亡き，(図7）

$$
\delta=\frac{\theta_{i}+\theta_{r}}{2}
$$

となる。図 7 の場合は $\delta$ は下向き方向となる。

理想平面矩形板からの反射断面積は，前述のごとく計算できるが奏際の部材は理想平面矩形板とはならず，面



図 6 bistatic cross section と monostatic cross section の換算方法

* G.T. Ruck: "Radar Cross Section Handbook", Vol. I, p.p. 11. 


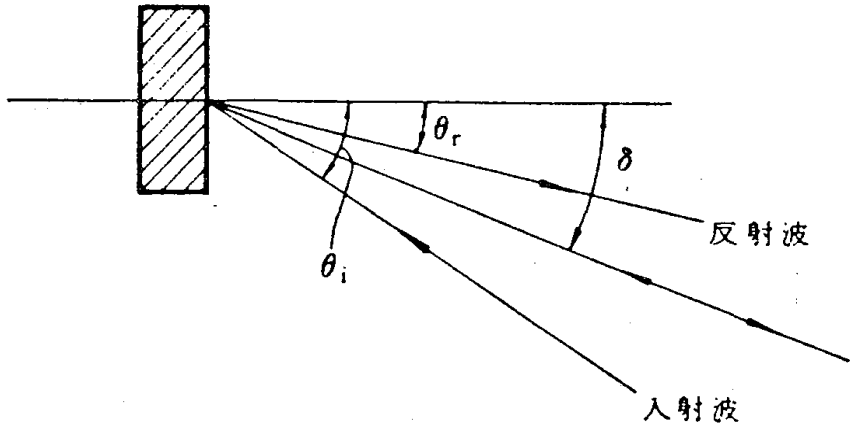

図 7 入射波と反射波が同一象限の場合

の凸凹，形状が矩形板ではなく任意形状で然す立体 的であることや，複数個の部材間の干渉などによ り，電波が散乱して一般に観測值は図 8 に示すどと く計算值より，ピーク值 $\sigma(0)$ が小さくなり，方位 $\theta$ に対するひろがり方は広く観測される。

とのととから，レーダー断面積は実際の寸法より 等価矩形で計算した方が現害とよく合致すると考え られる。ここで， $a_{e}, b_{e}$ は等価矩形寸法である。

$$
\left\{\begin{array}{l}
a_{e}=\sqrt{\alpha_{h}} \cdot a \\
b_{e}=\sqrt{\alpha_{v}} \cdot b
\end{array}\right.
$$

とおくと, $\sqrt{\alpha_{h}}, \sqrt{\alpha_{v}}$ はそれぞれ横と縦寸法の変換 係数となる。垂直入射の場合はピーク值となり，この反射断面積 $\sigma_{b}(0)$ は，理論值の

$$
\sigma_{b}(0)=\frac{4 \pi}{\lambda_{0}{ }^{2}}(a \times b)^{2}=\frac{4 \pi}{\lambda_{0}{ }^{2}} A^{2}
$$

に対して，実際は

$$
\sigma_{b e}(0)=\frac{4 \pi}{\lambda_{0}{ }^{2}}\left(a_{e} \times b_{e}\right)^{2}=\frac{4 \pi}{\lambda_{0}{ }^{2}} A_{e}{ }^{2}
$$

と表わせる。ピーク值の比は,

$$
\therefore \frac{\sigma_{b e}(0)}{\sigma_{b}(0)}=\alpha_{h} \cdot \alpha_{v}, \text { または } \frac{\sigma_{b e}(0)}{\sigma_{b}(0)}=\alpha_{h}+\alpha_{v}
$$

こで

$$
\sqrt{\alpha_{h} \cdot \alpha_{v}}<1
$$



図 8 反射断面積の観測値己計算值の比較

となり，てれは前述したごとき理由で反射電波が鏡面反射とならず 散乱を生ずるためである。

図 4 で示した斜め入，反射の monostatic 反射の場合は図 10 の ように $a \rightarrow a_{e}, \quad b \rightarrow b_{e}$ と拟て

$$
\begin{aligned}
\sigma_{b}(\theta, \phi) & =\frac{4 \pi}{\lambda_{0}{ }^{2}} A_{e}{ }^{2} \cdot \cos ^{2} \theta \cdot \cos ^{2} \phi \cdot\left[\frac{\sin \left(K_{0} a_{e} \sin \theta \cdot \cos \phi\right)}{K_{0} a_{e} \sin \theta \cdot \cos \phi}\right]^{2} \\
& \times\left[\frac{\sin \left(K_{0} b_{e} \sin \theta \cdot \sin \phi\right)}{K_{0} b_{e} \sin \theta \cdot \sin \phi}\right]^{2} \cdot\left[\frac{\sin \left(K_{0} b_{e} \sin \phi \cdot \cos \theta\right)}{K_{0} b_{e} \sin \phi \cdot \cos \theta}\right]^{2} \\
& \times\left[\frac{\sin \left(K_{0} a_{e} \sin \phi \cdot \sin \theta\right)}{K_{0} a_{e} \sin \phi \cdot \sin \theta}\right]^{2}
\end{aligned}
$$

$\phi \ll 1, \theta \ll 1$ とすると近似的に


図 9 等価矩形寸法 




図 10 monostatic radar cross section の近似法

$$
\sigma_{b}(\theta, \phi) \doteqdot \frac{4 \pi}{\lambda_{0}^{2}} A_{e}^{2} \cdot\left[\frac{\sin \left(K_{0} a_{e} \theta\right)}{K_{0} a_{e} \theta}\right]^{2} \cdot\left[\frac{\sin \left(K_{0} b_{e} \phi\right)}{K_{0} b_{e} \phi}\right]^{2}
$$

となる。さらに

$$
K_{0} a_{e} \theta \geqq \frac{\pi}{2}
$$

ならば（24）式は，

$$
\sigma_{b}(\theta, \phi) \div \frac{4 \pi}{\lambda_{0}{ }^{2}} A_{e}{ }^{2} \cdot\left(\frac{1}{K_{0} a_{e} \theta}\right)^{2} \cdot\left(\frac{1}{K_{0} b_{e} \phi}\right)^{2}
$$

で近似できる。(図 10)

図 11 のごとく橋を完全平面と 考え， $A$ 亡 $B$ 八斜め入射する場 合を考える。橋を完全平面とみな し，電波の進路を光のごとく鏡面 反射すると考えたとき，A点では 入射角が小さく，反射波ビームの 広がりが狭いので，狭いビーム幅 こなり，反射レベルが大きいはず である。 $B$ 点ではビームが広が り，反射レベルが小さくなるはず である。しかし，実測では逆に $A$ 点からの反射の方が広がったパタ ーンが観測されている。

このことは，反射波を考えると き，反射点 $A, B$ に执いて横幅 $L_{A}$ と $L_{B}$ のアンテナ放射と等価 となり，さら斜めに入射するほ ど正面より内部の部材の寄与分が 増加するためと考えないと説明が つかない。すなわ方完全平面から の反射と異なる反射パターンを示 के。

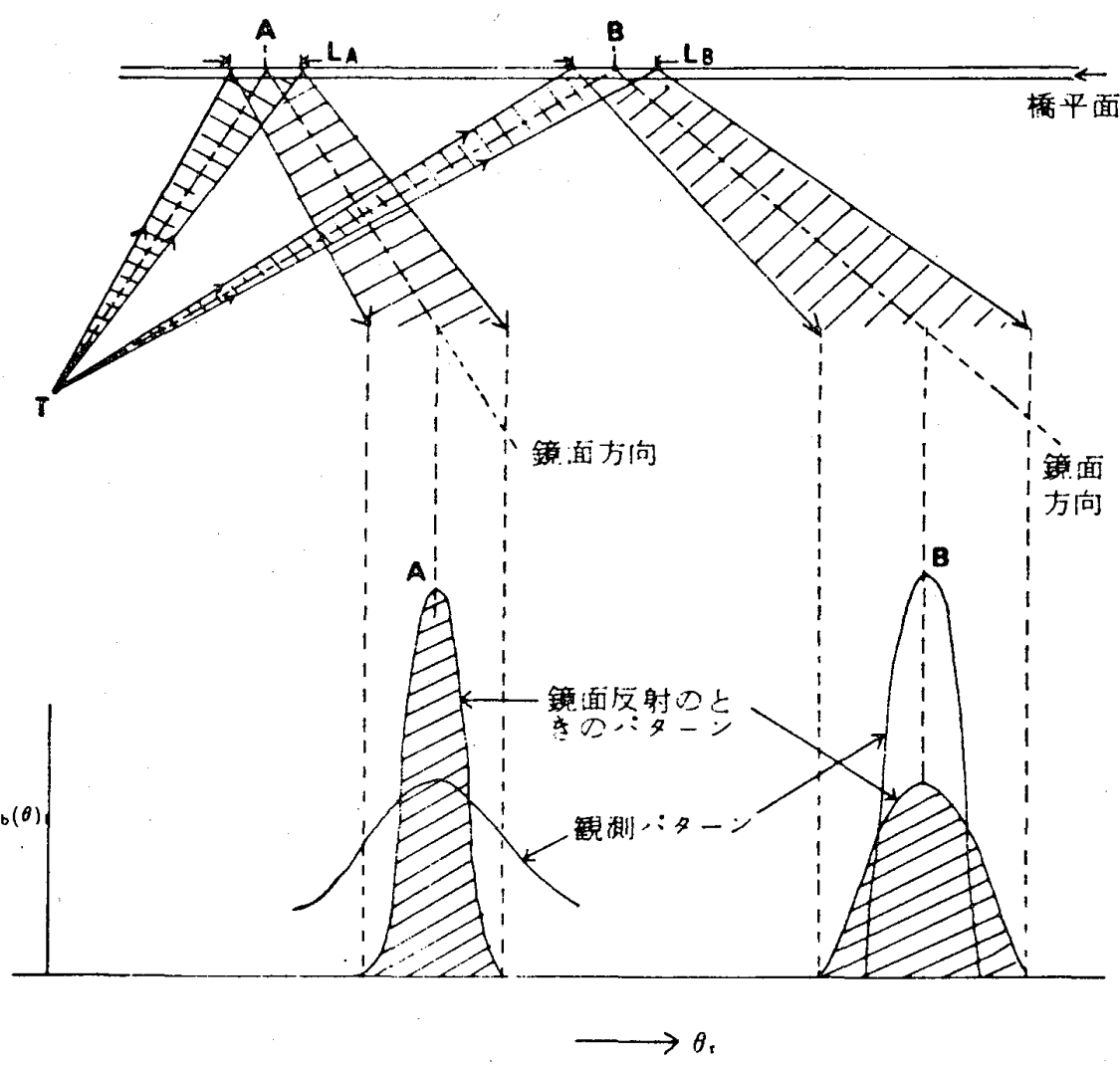

図 11 鏡面反射と笑測との反射パターンの差異 


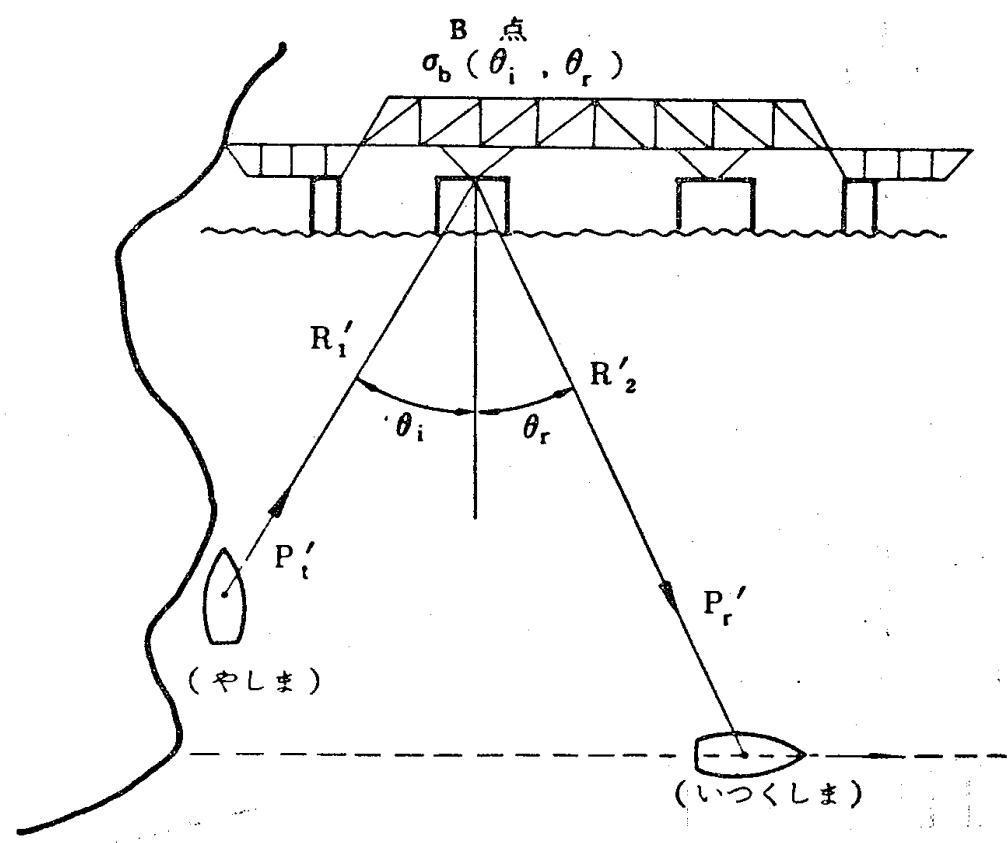

図 12 橋の反射指向特性の测定

図 12 は, 橋のレーダー反射断面積 $\sigma_{b}\left(\theta_{i}, \theta_{r}\right)$ を求めるための橋の反射指向特 性の観测方法を示した。「やしま」から発 射したレーダ一電波を橋で反射させ，「い つくしま」のレーダー受信機で受信した。 「いつくしま」が点線のごとき橋に平行し た航路を走って受信電力を観測すると，図 13 のごとき橋のレーダー反射指向特性が 得られる。横軸は方位角 $\theta_{r}$, 縦軸は受信 電力 $P_{r}^{\prime}$ で示した。

図 13 は大島大橋第 3 橋脚部 ( $B$ 点) か ら得られた反射波パターンであり，反射指 向特性は奏線で示すごとく複雑な変化の指 向特性をむっている。このデータを平滑し て点線のごとき特性を反射パターンと考え る。図13には横幅の小さい縦部材 $(50 \mathrm{~cm}$ 幅）からのビームのひろがりを計算した図 手した。縦部材からの反射波のひろがり は理論的には約 $0.1^{\circ}$ 位であり，横部材からの理論的なひろがりは $10^{-4 \circ}$ 位の鋭い指向性となるが，奏際には数 度位にひろがった指向特性が観測されている。このととは反射波の散乱と合成によるあのである。

複雑な橋材のごとく複合部材からの反射を解析的に計算するととは非常に困難であり，一般に理論値とかなり 異なる值を得ることが多い。理論的に合成阯面積は各部材の断面積の代数和ではなくぶクトル和となることにも よる。

図 14 のごとく面積が等しい物標が電波の方向に $1 / 4$ 波長ずれた位置にあると，反射方向の合成電界は零とな り， $\sigma_{b}=0$ と観測されるととです理解できる。一般に $n$ 個の物体があると，合成反射断面積 $\sigma_{0}$ は，べクトル 和として

$$
\dot{\sigma}_{0}=\sum_{j=1}^{n} \dot{\sigma}_{j}=\sum_{j=1}^{n}\left|\dot{\sigma}_{j}\right| e^{j \phi_{j}}
$$

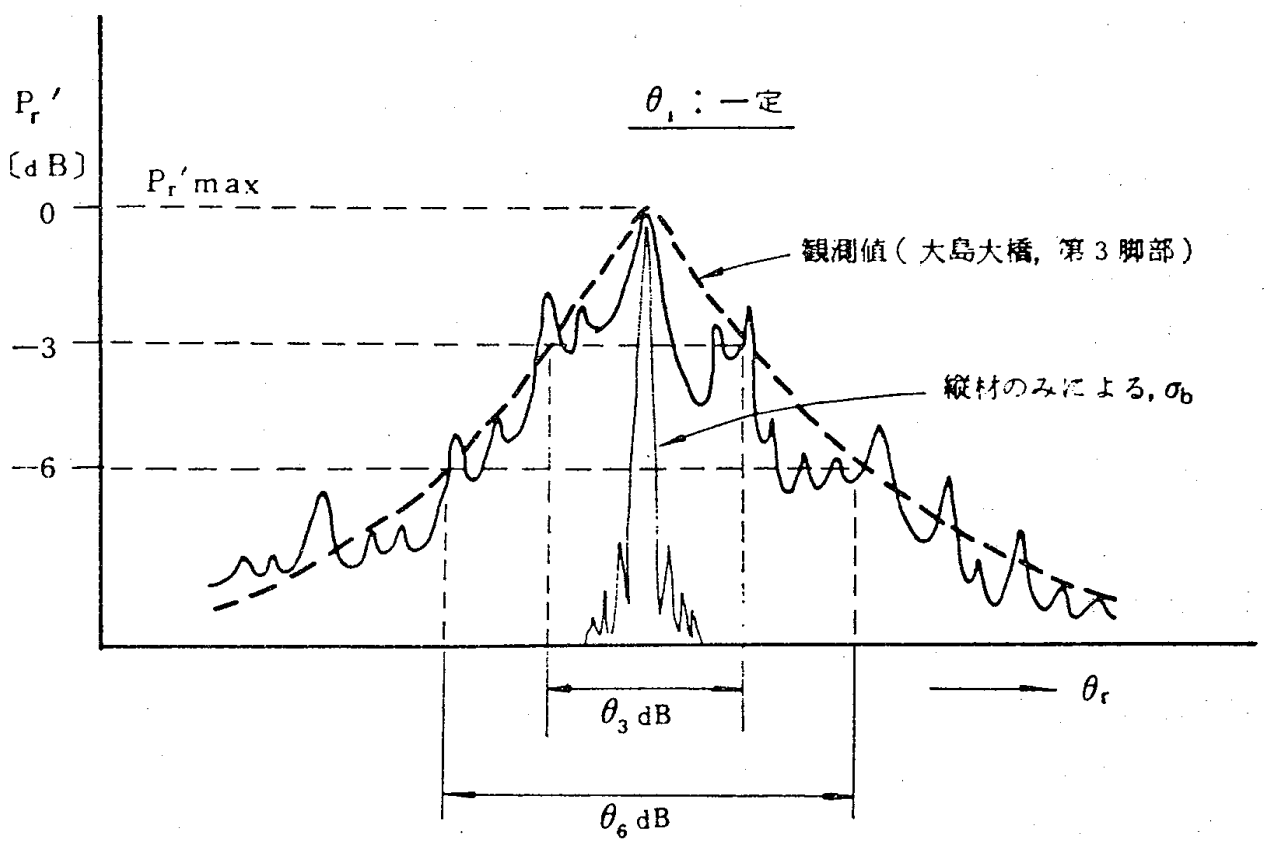

図 13 レーダー反射指向特性 
となる。 $\phi_{j}$ は $j$ 番目の位相差である。各部材の配列が全 くランダムだと $\dot{\sigma}_{b}$ の平均值 $\bar{\sigma}_{0}$ は,

$$
\bar{\sigma}_{0}=\sum_{j=1}^{n}\left|\dot{\sigma}_{j}\right|
$$

となり，代数和で求められる。

各部材反射波の位相が同相とすると最大值 $\sigma_{0} \max$ とな り

$$
\sigma_{0 \max }=\left(\sum_{j=1}^{n} \sqrt{\left|\dot{\sigma}_{j}\right|}\right)^{2}
$$

となる。例えば， 2 個の部材に対して
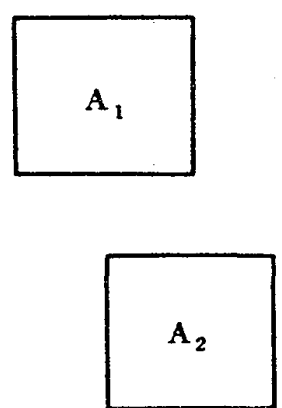

図 14反射方向の合成電界が零となる場合

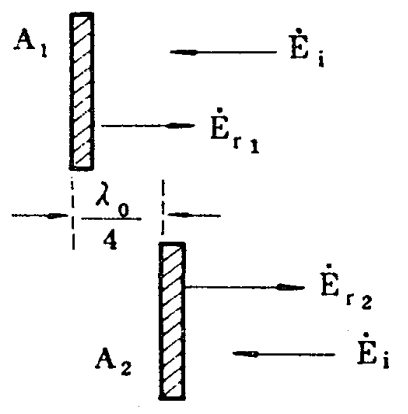

$$
\begin{array}{ll} 
& \bar{\sigma}_{0}=\sigma_{1}+\sigma_{2}, \\
\text { および } & \sigma_{0 \text { max }}=\sigma_{1}+\sigma_{2}+2 \sqrt{\sigma_{1} \cdot \sigma_{2}}
\end{array}
$$

となる。

ここで， $\sigma_{j}$ は $j$ 番目の部材からの反射断面積であり，各部材を等価矩形に置換えて考觉るとき（15)，(23） の両式より

$$
\begin{aligned}
\sigma_{j} & =\frac{4 \pi}{\lambda_{0}{ }^{2}}\left(a_{e j} \times b_{e j}\right)^{2} \cdot \cos ^{2} \delta_{\theta j} \cdot \cos ^{2} \delta_{\phi j} \cdot\left[\frac{\sin \left(K_{0} a_{e j} \cdot \sin \delta_{\theta j} \cdot \cos \delta_{\phi j}\right)}{K_{0} a_{e j} \cdot \sin \delta_{\theta j} \cdot \cos \delta_{\phi j}}\right]^{2} \\
& \times\left[\frac{\sin \left(K_{0} b_{e j} \cdot \sin \delta_{\theta j} \cdot \sin \delta_{\phi j}\right)}{K_{0} b_{e j} \cdot \sin \delta_{\theta j} \cdot \sin \delta_{\phi j}}\right]^{2} \cdot\left[\frac{\sin \left(K_{0} b_{e j} \cdot \sin \delta_{\phi j} \cdot \cos \delta_{\theta j}\right)}{K_{0} b_{e j} \cdot \sin \delta_{\phi j} \cdot \cos \delta_{\theta j}}\right]^{2} \\
& \times\left[\frac{\sin \left(K_{0} a_{e j} \cdot \sin \delta_{\phi j} \cdot \sin \delta_{\theta j}\right)}{K_{0} a_{e j} \cdot \sin \delta_{\phi j} \cdot \sin \delta_{\theta j}}\right]^{2}
\end{aligned}
$$

ここで,

$$
\left\{\begin{array}{c}
\delta_{\theta j}=\frac{\theta_{r j} \pm \theta_{i j}}{2} \\
\delta_{\phi j}=\frac{\phi_{r j} \pm \phi_{i j}}{2}
\end{array}\right.
$$

（複号は $\theta_{r j}$ と $\theta_{l j}$, または $\phi_{r j}$ と $\phi_{i j}$ がそれぞれ同一象限内にあるとき十をとる。）

$\delta_{\theta j} \ll 1 ， \delta_{\phi j} \ll 1$ なら (31) 式は近似的に

$$
\sigma_{j} \doteqdot \frac{4 \pi}{\lambda_{0}{ }^{2}}\left(a_{e j} \times b_{e j}\right)^{2} \cdot\left[\frac{\sin \left(K_{0} a_{e j} \cdot \delta_{\theta j}\right)}{K_{0} a_{e j} \cdot \delta_{\theta j}}\right]^{2} \cdot\left[\frac{\sin \left(K_{0} b_{e j} \cdot \delta_{\psi j}\right)}{K_{0} b_{e j} \cdot \delta_{\varphi j}}\right]^{2}
$$

となる。等価矩形寸法と部材寸法との間は，

$$
\left\{\begin{array}{l}
a_{e j}=\sqrt{\alpha_{h j}} \cdot a_{j} \\
b_{e i}=\sqrt{\alpha_{v j}} \cdot b_{j}
\end{array}\right.
$$

こかけ，係数 $\sqrt{\alpha_{h j}}, \sqrt{\alpha_{v j}}$ は理想平面に対して実際の部材から電波が散乱する度合を示す変換係数と考えられ る。

電波の散乱により鏡面反射方向の理想矩形反射断面積 $\sigma_{j}(0,0)$ は，実際の值 $\sigma_{e j}(0,0)$ に低下する。すなわち

$$
\begin{aligned}
\sigma_{j}(0,0)= & \frac{4 \pi}{\lambda_{0}{ }^{2}}(a \times b)^{2} \\
& \longrightarrow \sigma_{e j}(0,0)=\frac{4 \pi}{\lambda_{0}{ }^{2}}\left(a_{e} \times b_{e}\right)^{2}
\end{aligned}
$$

となる。同時に方位に対してひろがったパターンを示すようになる。

図 15 に水平方向 $\theta$ 成分について反射断面積のひろがりを示した。散乱による変換係数は, 部材の形状, 面の 凸凹，周波数，偏波面，複数部材間の干渉などにより定まる係数で正確な予測は困難である。反射断面積の観測 がなされていれば，各部材の平均的な変換係数を求めるてとができる。等価矩形を用いた（31）式または（33） 式は, 


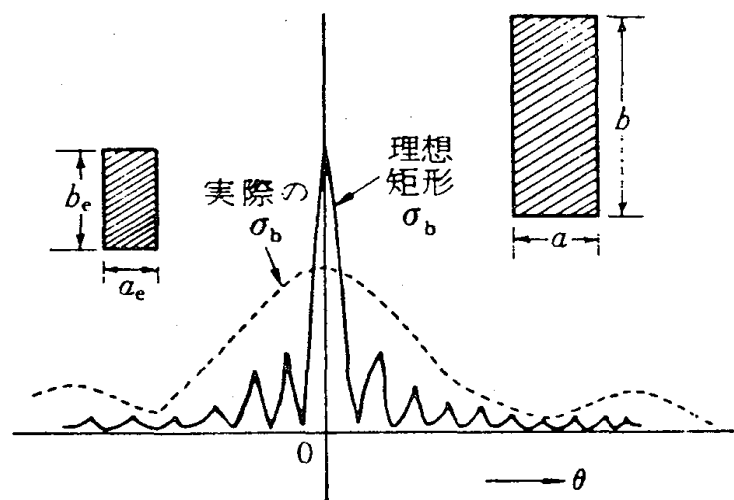

図 15 反射断面積のひろがり

$$
K_{0} a_{e} \delta_{\theta} \geqq \frac{\pi}{2}, \quad K_{0} b_{e} \delta_{\psi} \geqq \frac{\pi}{2}, \quad \delta_{\theta} \neq 0, \quad \delta_{\psi} \neq 0
$$

のとき

$$
\sigma_{j} \doteqdot-\frac{4 \pi}{\lambda_{0}{ }^{2}}\left(a_{e j} \times b_{e j}\right)^{2} \cdot\left(\frac{1}{K_{0} a_{e j} \delta_{\theta j}}\right)^{2} \cdot\left(\frac{1}{K_{0} b_{e j} \delta_{\phi j}}\right)^{2}
$$

で近似できる。

図 16 に大島大橋の反射特性を観測したときの配置を示 す。水平方向は鏡面反射点で $\theta_{i}=\theta_{r}$ となり，上下角 $\phi_{i}$ は， $\phi_{i}=\phi_{r}=\phi$ となる受信点に执いて $j$ 番目部材からの bistatic な反射断面積 $\sigma_{b}\left(\theta_{i}, \theta_{r}, \phi_{i}, \phi_{r}\right)$ は等価 monostatic 断面積に 置き換えて（15）式より

$$
\delta_{\theta}=\frac{\theta_{r}-\theta_{i}}{2}=0 \quad \text { および } \quad \delta_{\psi}=\frac{\phi_{i}+\phi_{r}}{2}=\phi_{j}
$$

となるので（33)，(35）式より

$$
\sigma_{j}\left(0, \phi_{j}\right) \div \sigma_{e j}(0,0)\left[\frac{\sin \left(K_{0} b_{e} \phi_{j}\right)}{K_{0} b_{e} \phi_{j}}\right]^{2}
$$

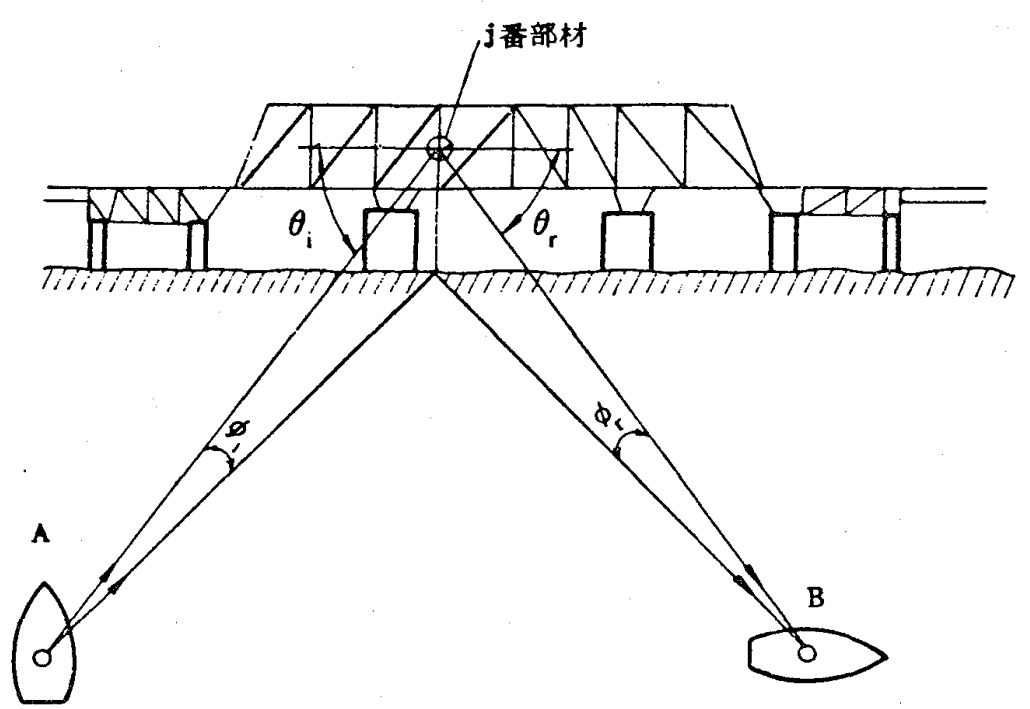

図 16 大島大橋の反射特性の観測

$$
\begin{aligned}
& \sigma_{e j}=\frac{4 \pi}{\lambda_{0}{ }^{2}}\left(a_{e j} \times b_{e j}\right)^{2} \\
& a_{e j}=\sqrt{\alpha_{h j}} \cdot a_{j} \quad \text { および } b_{e j}=\sqrt{\alpha_{v j}} \cdot b_{j}
\end{aligned}
$$

$a_{j}, b_{j}$ は $j$ 番目部材の横寸法之綐寸法である。 $\sqrt{\alpha_{h j}}$ と $\sqrt{\alpha_{v j}}$ は $j$ 番目部材からの反射波の散乱による 寸法の変換係数である。

図 17 に大島大橋中央部 ( $C$ 点) を示す。各部材に番号 をつけて区別する。綐材 4 本，斜材 3 本は $\phi$ 方向に対して 同一反射特性を示すので合わせて考えると，6種類の部材 からの合成反射を計算すればよい。合成反射断面積の平均 値をとると，

$$
\bar{\sigma}_{0}=\sum_{j=1}^{6} \sigma_{j}=\sigma_{1}+\sigma_{2}+4 \sigma_{3}+3 \sigma_{4}+\sigma_{5}+\sigma_{6}
$$

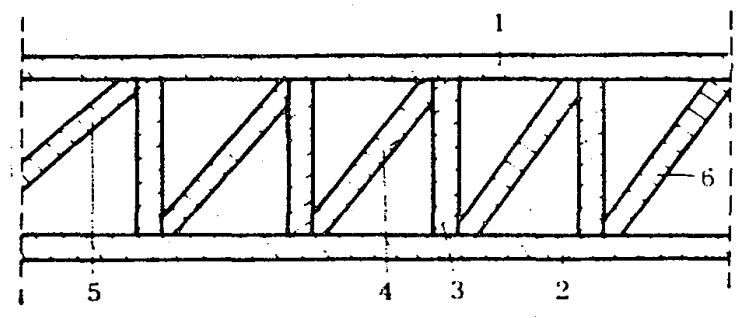

図 17 大島大橋中央部 ( $C$ 点) 
受信方向で同相に加わるときは， $\sigma_{0}$ は最大值となり，

$$
\begin{aligned}
\sigma_{0 \max } & =\left(\sum_{j=1}^{6} \sqrt{\sigma_{j}}\right)^{2} \\
& =\left(\sqrt{\sigma_{1}}+\sqrt{\sigma_{2}}+4 \sqrt{\sigma_{3}}+3 \sqrt{\sigma_{4}}+\sqrt{\sigma_{5}}+\sqrt{\sigma_{6}}\right)^{2}
\end{aligned}
$$

各部材の寸法, $a_{j}, b_{j}$, 入，反射角 $\phi_{i}$, 使用波長打よび変換係数 $\sqrt{\alpha_{j}}$ が求まれば（42）式または（43）式か ら受信方位における bistatic な反射断面積を計算することができる。奏際の部材からの合成は（42）式と（43） 式の間の值となると考えられる。

ここで, 変換係数 $\sqrt{\alpha_{j}}$ は, 部材からの散乱を考慮した值で, 各部材で異なる值を持つが, 照射範盲を一枚の 等価矩形汇置き換えると全部材からの平均変換係数 $\sqrt{\alpha}$ 北求められる。

大島大橋の反射パターンは, 図 16 の構成で観測した。水平方向 $(\theta)$ の反射特性は鋭いピーク值の集りとし て，観測された。

図 18 にその一例を示す。ことで, 各々の鋭いピークは各部材からのエレメントパターンであり, エンベロー プは散乱による合成のエネルギー分布特性である。橋の反射はエンベロープ特性で考える。各部材（ $j$ 番目）か らの合成を，図 19 のごとく一枚の等価矩形で考える。この場合の $a_{e}, b_{e}$ は散乱を考慮した等価横幅と縱幅で ある。そこで合成断面積 $\sigma_{0}$ は，

または

$$
\sigma_{0}(\theta, \phi)=\sum_{j} \sigma_{j} \quad \text { (平均值) }
$$

$$
\sigma_{0}(\theta, \phi)=\left(\sum_{j} \sqrt{\sigma_{j}}\right)^{2} \quad \text { (最大値) }
$$

であり， $\sigma_{j}$ は $j$ 番目部材の反射断面積

$$
\sigma_{j}(\theta, \phi)=\frac{4 \pi}{\lambda_{0}^{2}}\left(a_{e j} \times b_{e j}\right)^{2} \cdot D_{j}^{2}(\theta, \phi)
$$

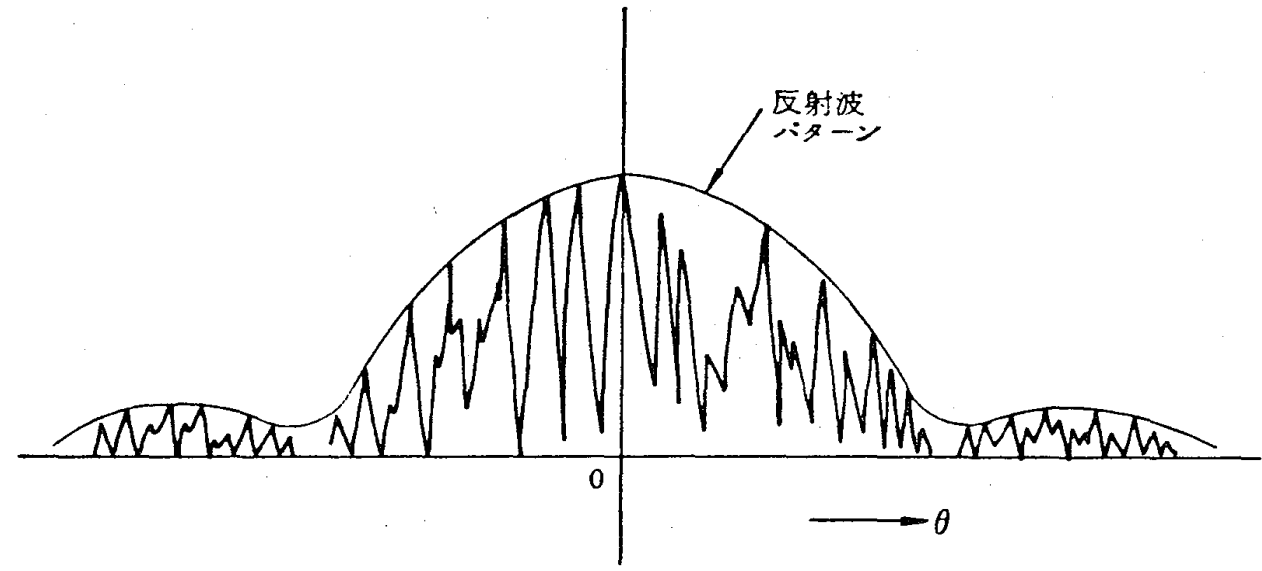

図 18 大島大橋に打ける水平方向 $(\theta)$ の反射特性の観貺結果一例
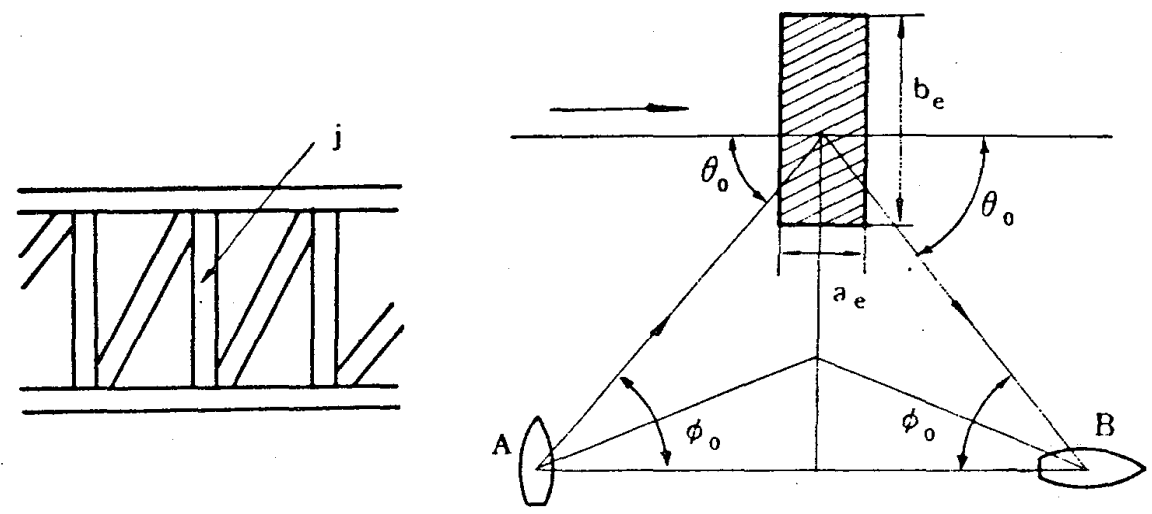

図 19 各部材 $(j$ 番目) 加らの合成 
である。ことで， $a_{e j}, b_{e j}$ は $j$ 番目部材の等洒横幅と縦幅であり， $D_{j}(\theta, \phi)$ は，指向特性を表わす。

$$
\begin{aligned}
& D_{0}{ }^{2}(\theta, \phi)=\left[\frac{\sin \left(K_{0} a_{e} \theta_{0}\right)}{K_{0} a_{e} \theta_{0}}\right]^{2} \cdot\left[\frac{\sin \left(K_{0} b_{e} \phi_{0}\right)}{K_{0} b_{e} \phi_{0}}\right]^{2} \\
& D_{j}{ }^{2}(\theta, \phi)=\left[\frac{\sin \left(K_{0} a_{e j} \theta_{j}\right)}{K_{0} a_{e j} \theta_{j}}\right]^{2} \cdot\left[\frac{\sin \left(K_{0} b_{e j} \phi_{j}\right)}{K_{0} b_{e j} \phi_{j}}\right]^{2}
\end{aligned}
$$

$\theta_{j}, \phi_{j}$ は, $j$ 番目部材への水平角亡上下角を表わす。

図 19 のごとく， $\theta$ に対して鏡面反射方向および上下角 $\phi$ が一定の位置で受信観測すると，合成断面積 $\sigma_{0}$ は

$$
\sigma_{0}(\theta, \phi)=\left[\frac{4 \pi}{\lambda_{0}{ }^{2}}(a \times b)^{2}\right] \cdot\left[\alpha_{n} \cdot \alpha_{v}\right] \cdot\left[\frac{\sin \left(K_{0} b_{e} \phi_{0}\right)}{K_{0} b_{e} \phi_{0}}\right]^{2}
$$

となる。第一項の［］は，照射されている部分の全面積からの反射，第二項の［］は散乱による理想平面か らの減少分，第三項の［］は指向方向による特性を表わしている。

乙の合成断面積は，例えば平均值では各部材断面積の和 $\sum_{j} \sigma_{j}$ で表わせる。すなわち，

$$
\begin{aligned}
\sigma_{0}(\theta, \phi) & =\sum_{j}\left[\frac{4 \pi}{\lambda_{0}{ }^{2}}\left(a_{j} \times b_{j}\right)^{2}\right] \cdot\left[\alpha_{h j} \cdot \alpha_{v j}\right] \\
& \times\left[\frac{\sin \left(K_{0} b_{j} \sqrt{\alpha_{v j}} \cdot \phi_{j}\right)}{K_{0} b_{j} \sqrt{\alpha_{v j}} \cdot \phi_{j}}\right]^{2}
\end{aligned}
$$

（49）式を書き直すと

$$
\sigma_{j}\left(\theta_{j}, \phi_{j}\right)=\left[\frac{4 \pi}{\lambda_{0}^{2}}\left(a_{j} \times b_{j}\right)^{2}\right] \cdot\left[\alpha_{h j} \cdot \alpha_{v j}\right] \cdot\left[D_{j}\left(\theta_{j}, \phi_{j}\right)\right]^{2}
$$

で表わせる。第一項の [ ] $j$ 番目部材を理想平面と考えたときの反射断面積，第二項の［］は，散乱を考 慮した変換係数で理想平面と実際の部材との相違を表わす。第三項の [ ] は，斜め方向の入，反射を考慮した 指向関数である。

図 16 で示したでとき測定系の配置構成に抢いて観測した場合について観測値と計算值とを比較してみる。

図 20 のごとく, 橋の一部の形状を近似させる。各部材に(1) (11)の番号を付し, 各部材の高さと観測したレ一 ダーの高さを右に示す。斜材の傾角 $\xi$ 表 1 亿示す。すべての部材を矩形と考える。部材(8)と(9)怙左刘称, (4) と(5)む左右対称である。

レーダー発射船は距離 $R=650 \mathrm{~m}$ 離れていた。各部材の諸元を表 2 に示す。

鏡面反射点で受信した場合を考える。（39）式より $j$ 番目部材の反射断面皘 $\sigma_{j}$ は，

$$
\begin{aligned}
\sigma_{j}\left(0, \phi_{j}\right) & =\sigma_{e j}(0,0) \cdot\left[\frac{\sin \left(K_{0} \cdot b_{e} \cdot \phi_{j}\right)}{K_{0} \cdot b_{e} \cdot \dot{\phi}_{j}}\right]^{2} \\
& =\left[\frac{4 \pi}{\lambda_{0}{ }^{2}}\left(a_{j} \times b_{j}\right)^{2}\right] \cdot\left[\alpha_{h j} \cdot \alpha_{v j}\right] \cdot\left[\frac{\sin \left(K_{0} b_{j} \sqrt{\alpha_{v j}} \cdot \phi_{j}\right)}{K_{0} b_{j} \sqrt{\alpha_{v j}} \cdot \phi_{j}}\right]^{2}
\end{aligned}
$$
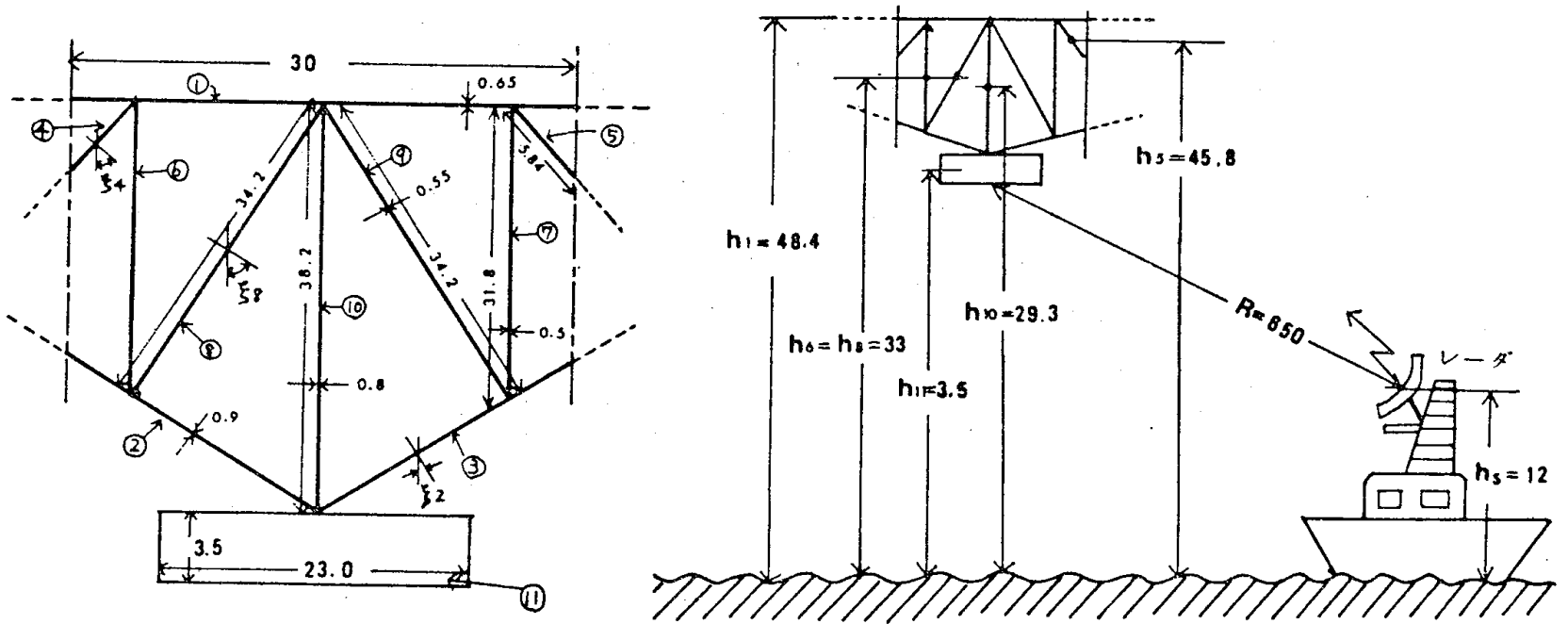

図 20 大島大橋, $P_{3}$ 部 $(B$ 点) 
で求められる。 $\sigma_{j}$ が求まれば合成断面積 $\sigma_{b}$ は，(44） 式で計算できる。

各部材に対して，上下，水平方向ともに鏡面方向 $\left(\phi_{j}=0\right)$ にあり，各部材は理想平面とすると，合成反 射断面積 $\sigma_{b}$ は,

(平均值) $\sigma_{b}=\sum_{j=1} \sigma_{j}=1.2 \times 10^{8}=(81 \mathrm{~dB})$

(最大值) $\quad \sigma_{b}^{\prime}=\left(\sum_{j=1} \sqrt{\sigma_{j}}\right)^{2}=6.9 \times 10^{8}=(88 \mathrm{~dB})$

となる。とれに対して奏際の観測值は約 $62 \mathrm{~dB}$ であった。との減少分は部材による散乱と斜め入射( $\left.\phi_{j} \neq 0\right) の$ ためと思われる。

表 2 各部材の諸元

\begin{tabular}{|c|c|c|c|c|c|c|c|c|c|c|c|}
\hline$N_{-1} j$ & (1) & (2) & (3) & $4:$ & (5) & (6) & $(7)$ & 绐 & (9) & (10) & (11. \\
\hline 横 幅 $\quad \mathbf{a}_{\mathbf{j}}$ & 30 & 0.9 & 0.9 & 0.55 & 0.55 & 0.5 & 0.5 & 0.55 & 0.55 & 0.8 & 3.5 \\
\hline 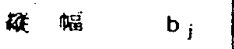 & 0.65 & 16.8 & 16.8 & 5.84 & 5.84 & 31.8 & 31.8 & 34.2 & 342 & 34.2 & 23.0 \\
\hline 面 機 $a_{j} \times b_{j}$ & 19.5 & 15.1 & 15.1 & 3.2 & 3.2 & 16 & 16 & 19 & 19 & 19 & 80 \\
\hline$o_{j}(0,0)\left(m^{2}\right)$ & $4.7 \times 10^{\circ}$ & $28 \times 10^{\circ}$ & $2.8 \times 10^{6}$ & $1.3 \times 10^{5}$ & $1.3 \times 10^{5}$ & $3.1 \times 10^{\circ}$ & $3.1 \times 10^{\circ}$ & $4.3 \times 10^{\circ}$ & $4.3 \times 10^{\circ}$ & $1.2 \times 10^{7}$ & $8 \times 10^{7}$ \\
\hline$a_{j}(0,0)(\mathrm{d} B)$ & 67 & 65 & 65 & 61 & 61 & 65 & 65 & 66 & 66 & 71 & 79 \\
\hline$\theta_{i}=\theta_{r} \quad(\operatorname{deg})$ & 30 & 30 & 30 & 30 & 30 & 30 & 30 & 30 & 30 & 30 & 30 \\
\hline$\phi_{j} \quad(d e g)$ & 3.1 & 0 & 0 & 3.0 & 3.0 & 1.7 & 1.7 & 17 & 17 & 1.4 & -0.8 \\
\hline$\phi_{;} \quad(\mathrm{rad})$ & 0054 & 0 & 0 & 0.051 & 0.051 & 0.03 & 0.03 & 0.03 & 0.03 & 0.0 .25 & -0.014 \\
\hline
\end{tabular}

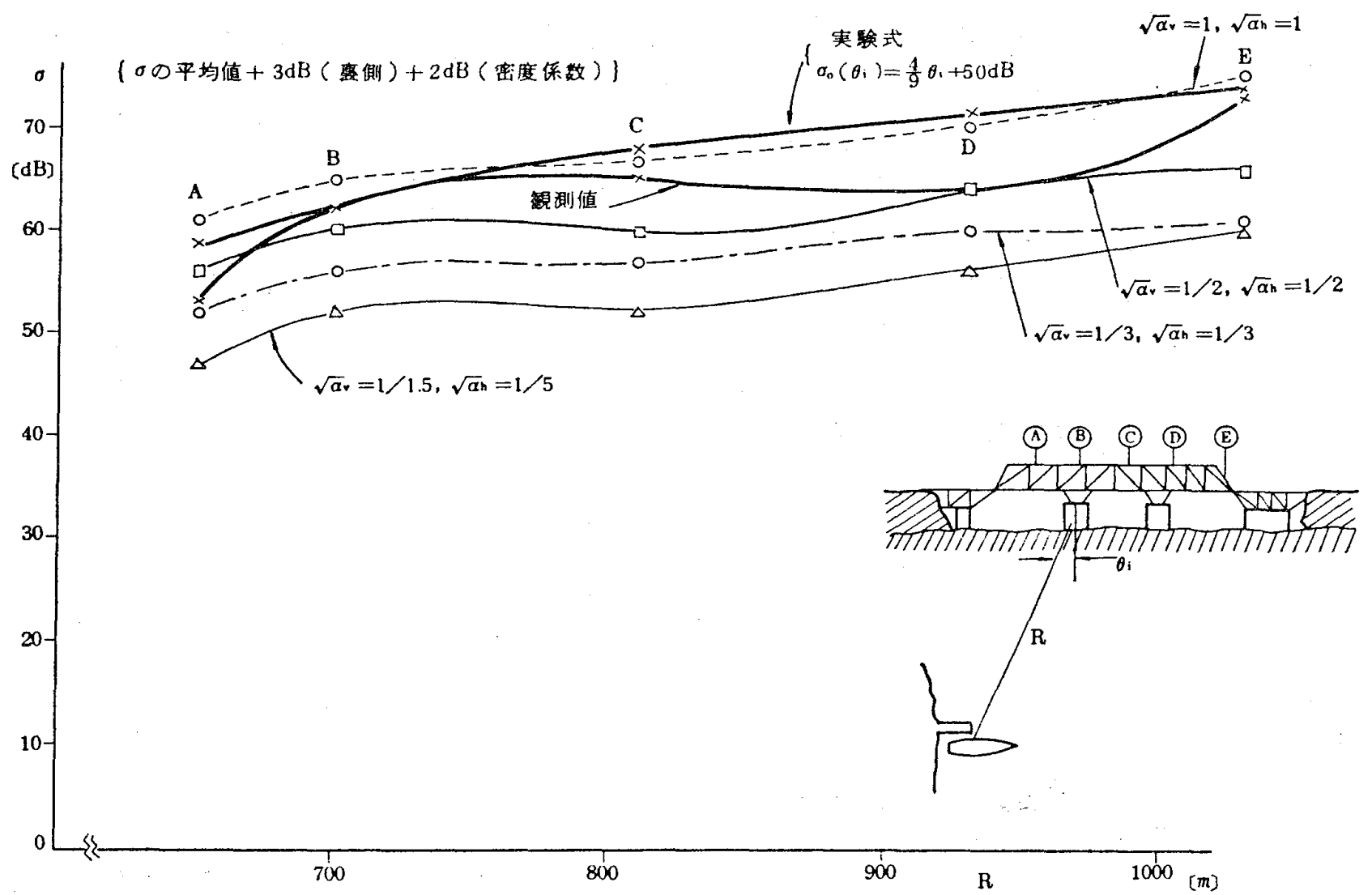

図 21 大島大橋反射断面積（平均） 
各部材への入射角は幾何学的に求められるが，散乱を考慮した変換係数の評価は観測值と理論值との比較によ り推定するめ外には求めることが困難である。

変換係数 $\alpha_{h j}$ と $\alpha_{v j}$ は各部材ごとに，部材を理想的矩形平面と考えたときと，実際に橋を構成している部材 との相違を表わしているもので，電波が部材から鏡面反射ではなく散乱する程度を示すことにすなるので，散乱 係数比とよふことができる。

$\alpha_{h j}, \alpha_{v j}$ は理論的に計算するととは不可能であり，実測值と理想的な部材としたときの計算值との比較で求め るしかない。

大島大橋を参考にして㬰測値と計算值を比較したグラフを図 21 および図 22 に示す。

大島大橋のレーダー反射断面積はレーダ一送信機が国鉄棧橋付近に固定しているので，橋のA・B・C・D お よび $\mathrm{E}$ 点に対応する反射点に対して一定の距離と入射角をすって照射したときの橋のレ一ダー反射断面皘しか観 测していない。

本節に打ける橋のレーダー反射断面積の計賞方法によれば，任意の距離と入射角（水平角上上下角）に対する 橋のレーダー反射断面積が計算できる。

図 21, 図 22 のグラフから平均值で考えると，変換係数 $\sqrt{\alpha_{v}}=1 / 2, \sqrt{\alpha_{h}}=1 / 2$ として計算した結果とよく一 致する。最大值で考えたときは $\sqrt{\alpha_{v}}=1 / 3, \sqrt{\alpha_{h}}=1 / 3$ が計算值と実測值がよく一致する值となっている。従っ て，大島大橋は $\sqrt{\alpha_{v}}=1 / 2 \sim 1 / 3, \sqrt{\alpha_{h}}=1 / 2 \sim 1 / 3$ として計算してよいととが推定できる。

上述の計算中には，補正項が含まれている。レーダ一反射断面積の計算は橋部材の船側の面だけに行い，裹側 6照射すると考えると 2 倍 $(+3 \mathrm{~dB})$ する必要があり，さらに横部材その他計算を省略した細い部材からの等与 分も考えると $2 \mathrm{~dB}$ を加え，合計として計算值に $5 \mathrm{~dB}$ を加えた值を橋のレーダ一反射断面積とした。

これらの結果を用いれば，任意の船の位置からの橋のレーダ一反射断面積が計算できることになる。

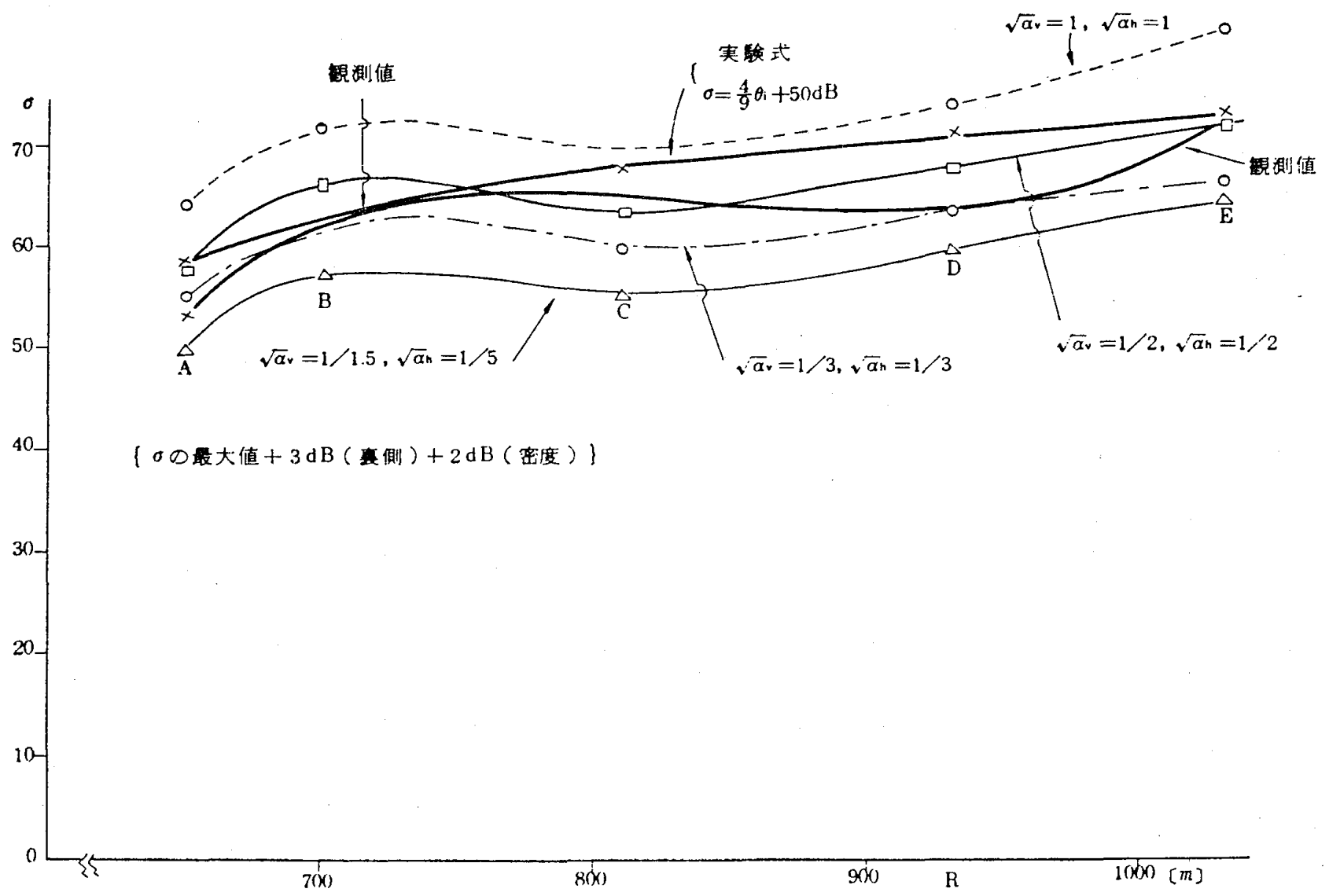

図 22 大島大橋反射断面積（最大） 


\section{5. ま と め}

本文では，まず橋によるレーダー偽像の受信電力レベルを求めるレーダー方程式を導き，その受信レベルを計 算するには橋のレーダー反射断面積を知る必要があることを述べた。次いで，橋のレーダー反射断面積を理論的 に求める方法を考察した。

その結果, 橋を矩形板の集合と考え, 実際の部材と理想平板との差異は変換係数の導入によって近似できるて とが分かった。具体的な計算例として大島大橋に预けるレーダー反射断面積を求め, 実測値と比較したとてろほ ぼ一致する結果が得られ，本計算法の妥当性が確認できた。

\section{質 疑 応 答}

萩野芳造：変換係数はどんな要素の関数になっていますか。

荒井郁男：部材の大きさ，形状面の凹凸，周波数，偏波面などで定まる係数であるが，正確な予測が困難なの

で，逆に変換係数をパラメーターとして計算し，観測值との比較により推定する方法をとった。

長沢 明: 橋に入射(あるいは反射) する際の仰角（俯角）についてはどのように評価されましたか。

荒井郁男: すべての部材について仰角む考虑して計算の中に含めた。

田ロ一夫: 計算式の最後の $+2 \mathrm{~dB}$ は橋の構造によって異なるか。

荒井郁男: 構造が複雑な程, 部材全部について計算に入れるととが困難になってくるので, とりとぼし分も多く

なる。その分だけ密度増加分としてさらに加味する必要がある。 